\title{
Price Spread of Kharif Groundnut in Solapur District of Maharashtra
}

\author{
S. L. Sawant*, R.D. Shelke and A.S. Rahane \\ Department of Agricultural Economics, College of Agriculture, Latur, India \\ *Corresponding author
}

\section{A B S T R A C T}

\begin{tabular}{|l|}
\hline Ke y w or d s \\
Groundnut, \\
Marketing channel, \\
Marketing cost, \\
Price spread
\end{tabular}

Groundnut is important oilseed crop in world and India also. The oil content depends on agro-climatic condition containing 44-50\% oil. The study was conducted to understand the nature of the marketing channels, marketing costs, market margins and price spread groundnut in Solapur district of Maharashtra. The data base consists of producer, wholesalers, and retailers of groundnut from whom primary data were collected by personal interviews with the help of pre tested schedule during 2019-20. Three marketing channels were identified in case of groundnut i.e. I) Producer-Consumer. II) Producer-Retailer-Consumer, III) Producer-Wholesaler-Retailer-Consumer). Per farm total production of groundnut was $26.32 \mathrm{qtl} / \mathrm{ha}$. Out of the total production $1.001 \mathrm{qtl}$ was retained for family consumption and left was marketed through different channels. Marketing cost for each channel was also calculated. Marketing Channel I was most efficient with Rs. 52.75 price spread and producer share in consumer rupee was 95.55 per cent. Price spread for channel- III was higher rather than other intermediaries.

\section{Introduction}

Groundnut having botanical name Arachis hypogea $L$. is the member of Fabiace family. It is important edible oilseed crop in the world. It is self pollinated crop. Arachis hypogeae comes from a Greek word means a legume and hypogeae means to the formation of pod in soil or below ground. Groundnut introduced in India by Portuguese during first half of the sixteenth century. It has been reported that Brazil was the place from where groundnut originated.
Groundnut is important oilseed crop in world and India also. The oil content depends on agro-climatic condition containing 44-50\% oil. It is edible oil owing that high content of digestible protein $(22-30 \%)$, vitamins $(\mathrm{E}, \mathrm{K}$, and B complex), minerals including phosphorus, calcium, magnesium, potassium and also contains some phyto sterol. In groundnut protein content $(25.2 \%)$, starch $(11.5 \%)$, soluble sugars $(4.5 \%)$, crude fibers $(2.1 \%)$, moisture $(6 \%)$. Total carbohydrate presents in it is 18.6 gram. Kernels used for consumption in raw and roasted form having 
calorific value 34 gram/100 gram. Groundnut oil cake contains 7 to $8 \% \mathrm{~N}, 1.5 \% \mathrm{P}, 1.2 \% \mathrm{~K}$ used as a fertilizers and supplement to animal and poultry also. Groundnut is legume crop used to symbiotic fixation of Nitrogen in soil. Groundnut contains one amino acid like a cystine used for animal growth. It contains some vitamins also Thiamine (1.14gm), Riboflavin (0.13gm), Niacin (17.2gm) in raw kernels. While in roasted kernels it contains $0.32 \mathrm{gm}, 0.13 \mathrm{gm}$, and $17.2 \mathrm{gm}$ respectively.

\section{Objective}

To study marketing channels and price spread in groundnut marketing.

\section{Materials and Methods}

Market channels for groundnut were identified by primary data from farmers, wholesalers, and retailers. A sample of 90 respondents including 60 farmers, 20 wholesalers, 10 retailers were randomly selected and interviewed based on pre tested schedule in Malshiras and Pandharpur taluka of Solapur district. Primary data regarding purchase price, marketing cost incurred, sale price and other related information were collected from the respondents. The data, thus collected was subjected to tabular analysis obtaining percentages.

\section{Results and Discussion}

\section{Major marketing channel in the study area}

Marketing channels reveal that produce passes through different agencies from producer to final consumer. In the study area following prominent channels were observed in the marketing,

i) Producer-- Consumer

ii) Producer--Retailer--Consumer

iii) Producer--Wholesaler--RetailerConsumer
Production, retention and marketed surplus of groundnut

Per farm production, retention, marketed surplus and marketing of groundnut through different marketing channels were accounted and presented in Table 1. The result obtained that, the average groundnut farm was 0.47 hectares. Groundnut production was 26.32 qtl. It was also observed that, the quantity of groundnut retained for home consumption was 1.001 qtl. Quantity of groundnut sold through channels-I was $6.31 \mathrm{qtl}$, Channel-II was 8.15 qtl and channel-III was 10.86 qtl. Total marketed surplus was 25.32 qtl.

\section{Marketing cost of groundnut incurred by different intermediaries}

\section{Marketing cost incurred by producer}

Per quintal marketing cost of groundnut incurred by producer in different marketing channels for different items were calculated and presented in Table 2. The result observed that, in channel-III, cost incurred by producer was higher as Rs.73.04 followed by Rs.67.69 in channel -II and Rs.52.75 in channel- I. In channel-I, packaging charges was higher i.e. Rs. 27.56(52.23 per cent), followed by transportation charges was Rs. 17.01(32.24 per cent), loading/ unloading charges was Rs.5.02(9.51 per cent) and weighing charges was Rs.3.16 (6.00 per cent).

\section{Marketing cost incurred by wholesaler}

Per quintal marketing cost of groundnut incurred by wholesaler in different marketing channels for different items were calculated and presented in Table 3. In channel- III, losses was higher i.e. Rs.15.5 (37.60 per cent) then followed by transportation charges was Rs.11.2 (27.14 per cent), storage charges was Rs. 5.02(12.2 per cent), loading/unloading charges was Rs.4.96 (12.02 per cent), 
weighing charges was Rs.3.23 (7.84 per cent), license and market fees were Rs. 0.45 (1.10 per cent) each and commission charges was Rs.0.40 (1.00 per cent). Therefore total marketing cost incurred by wholesaler was Rs. 41.21 (100 per cent).

\section{Marketing cost incurred by retailer}

Per quintal marketing cost of groundnut incurred by retailer was calculated and presented in Table 4. Cost incurred by retailer in channel-III was higher as Rs. 11.57 followed Rs. 10.18 in channel-II. In channelI, storage charges was higher i.e. Rs. 4.96(48.64 per cent) then followed by weighing charges was Rs. 3.8(37.3 per cent), losses was Rs. 0.50 (4.9 per cent), market fees was Rs. 0.43( 4.3 per cent), charges on shop tax was Rs. 0.25 (2.48) and license charges was Rs. 0.24(2.38 per cent). In channel- III, storage charges was higher i.e. Rs. 6.07(52.51 per cent) then followed by weighing charges was Rs. 3.26( 28.13 per cent), losses was Rs. 1.002 (8.66 per cent ), license charges was Rs. 0.36(3.13 per cent), market fees was Rs. 0.46(3.9 per cent) and shop tax was Rs. 0.42 (3.67 per cent).

\section{Price spread in groundnut marketing}

Per quintal marketing cost, marketing margin and price spread in marketing of groundnut with regards to different channels were calculated and presented in Table 5. It resulted that, in channel-I net price received by producer from consumer was Rs.4949.17 while cost incurred by producer was Rs.52.75. The price paid by consumer was Rs.5001.92, thus price spread was found to be Rs.52.75. In channel-I producers share in consumer's rupee was found to be 95.55 per cent.

In channel-II net price received by producer from retailer was Rs.4817.06 while cost incurred by producer was Rs. 67.69. Price paid by retailer was Rs.4884.75. The cost incurred by retailer and margin of retailer was Rs.10.18 and Rs.171.75, respectively. The price paid by consumer was Rs. 5066.68. Thus, price spread was found to be Rs.249.62. In channel-II producer's share in consumer's rupee was found to be 86.04 per cent. It was clear that from following table, producer's share in consumer's rupee was maximum in channel-I. It was finding that, marketing cost in channel-I was 52.75. Thus price spread was found to be Rs.52.75. In Channel-II marketing cost was 77.87 and margin was Rs.171.75. Thus price spread was found to be Rs.249.62.

In channel-III, net price received by producer from consumer was Rs. 4713. Cost incurred by producer was Rs. 73.04 therefore price paid by wholesaler was Rs.4786.04. Cost incurred by wholesaler was Rs. 41.21 and margin of wholesaler was Rs. 31.02 therefore price paid by retailer was Rs. 4858.27. Cost and margin of retailer were Rs. 11.57 and Rs. 145.27 respectively. Therefore, price paid by consumer was Rs.5015.11. Price spread was Rs.302.11. It was clear that from table, cost was Rs. 125.82 and margin was Rs. 176.29. Thus price spread was found that Rs. 302.11. Producer share in consumer rupee was 76 per cent.

In conclusion, three marketing channels were identified in case of groundnut (i.e. I. Producer-Consumer. II. Producer-RetailerConsumer and III. Producer-WholesalerRetailer-Consumer). Among marketing cost incurred by different intermediaries marketing cost of wholesaler was highest and cost incurred by producer was lowest. Channel I was most efficient with 52.75 price spread and 95.55 per cent producer's share in consumer rupee because the produce was directly marketed from producer to consumer. And price spread was highest in the channel III where number of intermediaries was also more. 
Table.1 Per farm production, retention and marketed surplus of groundnut

\begin{tabular}{|c|l|c|}
\hline Sr. No. & \multicolumn{1}{|c|}{ Particulars } & Groundnut farm \\
\hline $\mathbf{1}$ & Groundnut farm size (ha) & 0.47 \\
\hline $\mathbf{2}$ & Production of groundnut(q) & 26.32 \\
\hline $\mathbf{3}$ & Retention of groundnut for consumption(q) & 1.001 \\
\hline $\mathbf{4}$ & Marketed surplus in channel-I(q) & 6.31 \\
& (Producer-Consumer) & $(24.7)$ \\
\hline $\mathbf{5}$ & Marketed surplus in channel-II(q) & 8.15 \\
& (Producer-Retailer-Consumer) & $(32.4)$ \\
\hline $\mathbf{6}$ & Marketed surplus in channel-III(q) & 10.86 \\
& (Producer-Wholesaler-Retailer-Consumer) & $(42.9)$ \\
\hline $\mathbf{7}$ & Total marketed surplus(q) & 25.32 \\
& & $(100)$ \\
\hline
\end{tabular}

(Figure in parenthesis is the percentage to the marketed surplus in different channel)

Table.2 Marketing cost incurred by groundnut producer in different channels

\begin{tabular}{|c|c|c|c|c|}
\hline & & & & Rs/qtl \\
\hline Sr. No & Particulars & $\begin{array}{l}\text { Channel- I } \\
\text { (Producer- } \\
\text { Consumer) }\end{array}$ & $\begin{array}{c}\text { Channel-II } \\
\text { (Producer- } \\
\text { Retailer- } \\
\text { Consumer) }\end{array}$ & $\begin{array}{l}\text { Channel-III } \\
\text { (Producer- } \\
\text { Wholesaler } \\
\text { Retailer- } \\
\text { (Consumer) }\end{array}$ \\
\hline 1. & $\begin{array}{l}\text { Loading/unloading } \\
\text { charges }\end{array}$ & $\begin{array}{c}5.02 \\
(9.51)\end{array}$ & $\begin{array}{c}5.41 \\
(7.99)\end{array}$ & $\begin{array}{c}5.51 \\
(7.54)\end{array}$ \\
\hline 2. & Transportation charges & $\begin{array}{c}17.01 \\
(32.24)\end{array}$ & $\begin{array}{c}10.84 \\
(16.01)\end{array}$ & $\begin{array}{c}8.97 \\
(12.28)\end{array}$ \\
\hline 3. & Weighing charges & $\begin{array}{c}3.16 \\
(6.00)\end{array}$ & $\begin{array}{c}4 \\
(5.90)\end{array}$ & $\begin{array}{c}3.22 \\
(4.41)\end{array}$ \\
\hline 4. & Packaging charges & $\begin{array}{c}27.56 \\
(52.23)\end{array}$ & $\begin{array}{c}31.97 \\
(47.23)\end{array}$ & $\begin{array}{l}39.8 \\
(54.5)\end{array}$ \\
\hline 5. & Commission charges & - & $\begin{array}{c}15.47 \\
(22.87)\end{array}$ & $\begin{array}{c}15.54 \\
(21.27)\end{array}$ \\
\hline & TOTAL & $\begin{array}{l}52.75 \\
(100)\end{array}$ & $\begin{array}{l}67.69 \\
(100)\end{array}$ & $\begin{array}{l}73.04 \\
(100)\end{array}$ \\
\hline
\end{tabular}

(Figure in parenthesis is the percentage to the cost incurred by producer) 
Table.3 Marketing cost incurred by wholesaler in channel-III

\begin{tabular}{|c|l|c|}
\hline \multicolumn{1}{|c|}{ Sr. No } & Particulars & Channel-III \\
\hline $\mathbf{1 .}$ & Storage charge & 5.02 \\
\hline $\mathbf{2 .}$ & License charges & $(12.2)$ \\
\hline $\mathbf{3 .}$ & Loading/Unloading charges & 0.45 \\
& & $(1.10)$ \\
\hline $\mathbf{4 .}$ & Weighing charges & 4.96 \\
\hline $\mathbf{5 .}$ & Transportation charges & $(12.02)$ \\
\hline $\mathbf{6 .}$ & Market fees & 3.23 \\
\hline & & $(7.84)$ \\
\hline $\mathbf{7 .}$ & Commission charges & 11.2 \\
& & $(27.14)$ \\
\hline $\mathbf{8 .}$ & Losses & 0.45 \\
& & $(1.10)$ \\
\hline & TOTAL & 0.40 \\
& & $1.00)$ \\
\hline
\end{tabular}

(Figure in parenthesis is the percentage to the cost incurred by wholesaler)

Table.4 Marketing cost incurred by retailer

\begin{tabular}{|c|l|c|c|}
\hline Sr.No. & Particulars & Channel-II & Channel-III \\
\hline $\mathbf{1 .}$ & Weighing charges & 3.8 & 3.26 \\
\hline $\mathbf{2 .}$ & License charge & $(37.3)$ & $(28.13)$ \\
\hline $\mathbf{3 .}$ & Losses & 0.24 & 0.36 \\
& & $(2.38)$ & $(3.13)$ \\
\hline $\mathbf{4 .}$ & Market fees & 0.50 & 1.002 \\
& & $(4.9)$ & $(8.66)$ \\
\hline $\mathbf{5 .}$ & Shop tax & 0.43 & 0.46 \\
& & $(4.3)$ & $(3.9)$ \\
\hline $\mathbf{6 .}$ & Storage charges & 0.25 & 0.42 \\
& & $(2.48)$ & $(3.67)$ \\
\hline & TOTAL COST & 4.96 & 6.07 \\
& & $\mathbf{( 4 8 . 6 4 )}$ & $\mathbf{( 5 2 . 5 1 )}$ \\
\hline & & $\mathbf{1 0 . 1 8}$ & $\mathbf{1 1 . 5 7}$ \\
\hline
\end{tabular}


Table.5 Per quintal marketing cost, margin and price spread in groundnut

\begin{tabular}{|c|c|c|c|c|}
\hline Sr. No & Particulars & Channel-I & Channel-II & Channel-III \\
\hline 1 & $\begin{array}{l}\text { Net price received by } \\
\text { producer(producer share in } \\
\text { consumer rupee) }\end{array}$ & $\begin{array}{r}4949.17 \\
(95.55)\end{array}$ & $\begin{array}{l}4817.06 \\
(86.04)\end{array}$ & $\begin{array}{c}4713 \\
(76.00)\end{array}$ \\
\hline 2 & Cost incurred by producer & $\begin{array}{l}52.75 \\
(4.45)\end{array}$ & $\begin{array}{l}67.69 \\
(4.25)\end{array}$ & $\begin{array}{l}73.04 \\
(3.06)\end{array}$ \\
\hline 3 & Price paid by wholesaler & - & - & $\begin{array}{c}4786.04 \\
(79.06)\end{array}$ \\
\hline 4 & Cost incurred by Wholesaler & - & - & $\begin{array}{l}41.21 \\
(3.55)\end{array}$ \\
\hline 5 & Margin of wholesaler & - & - & $\begin{array}{l}31.02 \\
(2.50)\end{array}$ \\
\hline 6 & Price paid by retailer & - & $\begin{array}{c}4884.75 \\
(90.29)\end{array}$ & $\begin{array}{c}4858.27 \\
(85.11)\end{array}$ \\
\hline 7 & Cost incurred by retailer & - & $\begin{array}{l}10.18 \\
(1.65)\end{array}$ & $\begin{array}{l}11.57 \\
(1.85)\end{array}$ \\
\hline 8 & Margin of retailer & - & $\begin{array}{l}171.75 \\
(8.06)\end{array}$ & $\begin{array}{l}145.27 \\
(13.04)\end{array}$ \\
\hline 9 & Price paid by consumer & $\begin{array}{c}5001.92 \\
(100)\end{array}$ & $\begin{array}{c}5066.68 \\
(100)\end{array}$ & $\begin{array}{c}5015.11 \\
(100)\end{array}$ \\
\hline 10 & Marketing cost & $\begin{array}{l}52.75 \\
(4.45)\end{array}$ & $\begin{array}{c}77.87 \\
(5.9)\end{array}$ & $\begin{array}{l}125.82 \\
(8.46)\end{array}$ \\
\hline 11 & Marketing margin & - & $\begin{array}{l}171.75 \\
(9.56)\end{array}$ & $\begin{array}{l}176.29 \\
(13.00)\end{array}$ \\
\hline 12 & Price Spread & $\begin{array}{l}\mathbf{5 2 . 7 5} \\
\mathbf{( 4 . 4 5 )}\end{array}$ & $\begin{array}{l}249.62 \\
(15.46)\end{array}$ & $\begin{array}{l}302.11 \\
(21.46)\end{array}$ \\
\hline
\end{tabular}

(Figure in parenthesis is the percentage to the marketing cost, margin price spread)

\section{References}

Chatse, D.B., Perke, D.S., and Shelke R.D., (2018). Economic Analysis of Marketing of Summer Groundnut in Hingoli district of Maharashtra State, India. International Journal of Current Microbiology and Applied Sciences, 7 (8):2022-2027.

Chavhal, S.H., Katkade, J.L., Kauthekar, P.U., Chavan, R.V. and Sudewad L.S., (2014). Marketing cost, marketing margin and price spread of soybean in Parbhani district of Maharashtra. International Journal of Commerce and
Business Management, 7 (2):334-337. Maurya, S.K., Kushwaha, R.R., Mourya, K.K. and Sarvesh Kumar, (2017). Price spread and marketing efficiency of groundnut marketing in Gorakhpur Districts of Eastern U.P. Journal of Pharmacognosy and Phytochemistry, 6(6): 712-715.

Perke, D. S., Puri, R.V. and More, S.S., (2017). Marketing cost, marketing margin and price spread of Soybean in Hingoli Market. Bulletin of Environment, Pharmacology and Life Sciences, 6 (3):217-220. 


\section{How to cite this article:}

Sawant, S.L., R. D. Shelke and Rahane, A.S. 2020. Price Spread of Kharif Groundnut in Solapur District of Maharashtra. Int.J.Curr.Microbiol.App.Sci. 9(11): 2622-2628. doi: https://doi.org/10.20546/ijcmas.2020.911.317 